\title{
PENGARUH INTERAKSI PACLOBUTRAZOL DAN TIPE TANAM JAJAR LEGOWO PADA PRODUKSI PADI METODE TANAM SRI
}

\author{
Christiane M. Tambajong \\ Edy Lengkong \\ David S. Runtunuwu
}

\begin{abstract}
This study aims to find the effect of interaction of paclobutrazol and type Legowo Row Planting in paddy fields that use SRI cultivation method to increase rice yield, and can determine the best combination of effective and can be applied in paddy fields to increase production. The research was conducted in the Village of Sulu, Tatapaan Sub-district, South Minahasa Regency. This study uses a field experiment with split plot design in groups of two factors. As the first factor is the type of Legowo Row Planting 2: 1 and 4: 1. The second factor is the provision of paclobutrazol by spraying the plants with a dose of: 0 ppm and $600 \mathrm{ppm}$. Paclobutrazol will be given only once, that when plants in active vegetative growth period (about 30 days old plants after transplanting). Data analysis was used Two-Factor Interactions calculation. The interaction of two factors occured, if the effect of a factor changes when the change level of other factors change. The results indicated that the existence of interaction between treatment paclobutrazol and Legowo row that high interaction in the inhibition of the vegetative growth of rice crops varieties Serayu, middle interactions on the rate of plant growth, middle interactions in the treatment of paclobutrazol and Legowo row to increase the content of chlorophyll a and chlorophyll $b$ in the leaves, the influence of high interaction of the number of productive tillers, high interaction on panicle length, high interaction to the increased weight of 1,000 grains, high interaction of the increase in the weight of dry unhusked rice per plot, and the lack of interaction to increase the number of grains per panicle. Paclobutrazol 600 ppm treatment gave a positive response on Legowo row 2: 1 for the inhibition of vegetative growth of crops to prevent crop is too high and not easily fall, increased chlorophyll a, increasing the weight of 1,000 grains and increased the weight of milled rice per plot. Paclobutrazol 600 ppm treatment gave a positive response on Legowo row 4: 1 to increase the pace of growth, increased chlorophyll $b$, an increase in the number of productive tiller and panicle length.
\end{abstract}

Keywords: $\quad$ Paclobutrazol, Planting Jajar Legowo, Rice Production, Sri Planting Method, Sulu Village, Sub-district of Tatapaan, South Minahasa District

\begin{abstract}
ABSTRAK
Penelitian ini bertujuan untuk menemukan pengaruh interaksi paclobutrazol dan tipe tanam jajar legowo di lahan sawah yang menggunakan cara budidaya SRI terhadap peningkatan hasil padi serta dapat menentukan kombinasi terbaik yang efektif dan dapat diterapkan di lahan sawah untuk peningkatan produksi. Penelitian dilaksanakan di Desa Sulu, Kecamatan Tatapaan, Kabupaten Minahasa Selatan. Penelitian ini menggunakan metode percobaan lapangan dengan rancangan petak terbagi dalam kelompok dari dua faktor. Sebagai faktor pertama adalah tipe tanam jajar legowo 2:1 dan 4:1. Sedangkan faktor kedua adalah pemberian paclobutrazol melalui penyemprotan pada tanaman dengan dosis: $0 \mathrm{ppm}$ dan $600 \mathrm{ppm}$. Paclobutrazol akan diberikan hanya sekali, yaitu pada saat tanaman dalam periode pertumbuhan vegetatif aktif (tanaman berumur sekitar 30 hari setelah pindah tanam). Data analisis menggunakan perhitungan Interaksi Dua Faktor. Dua faktor dikatakan berinteraksi apabila pengaruh suatu faktor berubah pada saat perubahan taraf faktor lainnya berubah. Hasil penelitian ini menunjukkan adanya interaksi antara perlakuan paclobutrazol dan jajar legowo yaitu interaksi tinggi pada penghambatan pertumbuhan vegetatif tanaman padi sawah varitas Serayu, interaksi pertengahan terhadap laju tumbuh tanaman, interaksi pertengahan pada perlakuan paclobutrazol dan jajar legowo untuk peningkatan kandungan klorofil a dan klorofil b pada daun, adanya pengaruh interaksi yang tinggi terhadap jumlah anakan produktif, interaksi yang tinggi pada panjang malai, interaksi yang tinggi terhadap peningkatan berat 1.000 butir, interaksi yang tinggi terhadap peningkatan berat Gabah Kering Giling per petak, dan tidak adanya interaksi terhadap peningkatan jumlah butir per malai. Perlakuan paclobutrazol 600 ppm memberikan respon positif pada jajar legowo 2:1 untuk penghambatan pertumbuhan vegetative tanaman untuk mencegah tanaman terlalu tinggi dan tidak mudah rebah, peningkatan kandungan klorofil a, meningkatkan berat 1.000 butir dan meningkatkan berat gabah kering giling per petak. Perlakuan paclobutrazol 600 ppm memberikan respon positif pada jajar legowo 4:1 untuk peningkatan laju tumbuh, peningkatan kandungan klorofil $b$, peningkatan jumlah anakan produktif dan panjang malai.
\end{abstract}

Kata Kunci : Paclobutrazol, Tanam Jajar Legowo, Produksi Padi, Metode Tanam Sri, Desa Sulu, Kecamatan Tatapaan, Kabupaten Minahasa Selatan 


\section{PENDAHULUAN}

Indonesia dikenal sebagai negara agraris karena sebagian besar rakyatnya hidup dari pertanian. Pada awalnya kondisi alam, cuaca dan budaya masyarakat di Indonesia sangat mendukung sektor pertanian, dimana tanah Indonesia merupakan tanah yang sangat subur dan produktif sehingga pertanian memang cocok untuk terus dikembangkan di Indonesia. Pada perkembangannya secara umum semakin lama kondisi tanah pertanian di Indonesia semakin rendah tingkat kesuburannya yang berdampak kepada semakin menurunnya tingkat produksi pertanian.

Persoalan lain yang dihadapi pada peningkatan produksi tanaman padi yaitu kerusakan tanaman akibat serangan angin kencang yang mengakibatkan tanaman rebah serta serangan hama, penyakit dan gulma yang menurunkan produksi. Melihat kondisi tersebut dipandang penting untuk mengupayakan rekayasa teknologi budidaya yang dapat memperkokoh tanaman padi dan juga metode tanam yang sesuai untuk pertumbuhan tanaman dan kemudahan petani mengendalikan serangan hama dan gulma secara mekanis tanpa merusak tanaman padi yang telah ditanam serta mempermudah pengaplikasian pupuk tanaman demi mempertahankan hasil.

Salah satu jenis zat penghambat tumbuh atau retardan yaitu paclobutrazol. Zat penghambat tumbuh ini dapat menghambat perpanjangan batang, meningkatkan zat hijau daun, meningkatkan partisi karbohidrat dan secara tidak langsung akan mendorong pembungaan tanpa menyebabkan pertumbuhan abnormal (Wattimena, 1988). Runtunuwu, dkk, (2013) menyatakan dosis aplikasi paclobutrazol yang dapat digunakan untuk menghasilkan tanaman padi yang pendek dengan produktivitas yang lebih tinggi adalah 400 ppm sampai 600 ppm.

Disamping hal tersebut di atas, upaya rekayasa teknologi budidaya yang sedang dikembangkan saat ini yaitu metode tanam jajar legowo, metode tanam ini merupakan metode tanam padi sawah yang memiliki beberapa barisan tanaman kemudian diselingi dengan 1 baris kosong. Wahyu (2010) menyatakan bahwa pelaksanaan metode tanam jajar legowo memiliki beberapa keunggulan, seperti tanaman padi dapat lebih banyak memanfaatkan sinar matahari, dapat mengurangi serangan hama, menekan serangan penyakit karena kelembaban yang semakin berkurang, mempermudah pelaksanaan pemupukan dan pengendalian hama penyakit juga mampu meningkatkan populasi tanaman. Menurut Wahyu (2010) terdapat modifikasi beberapa tipe jajar legowo namun dari hasil penelitian, tipe terbaik adalah tipe jajar legowo 4:1 dan tipe jajar legowo 2:1.

\section{Tujuan Penelitian}

Tujuan penelitian ini adalah untuk menemukan pengaruh interaksi paclobutrazol dan tipe tanam jajar legowo di lahan sawah yang menggunakan cara budidaya SRI terhadap peningkatan hasil padi serta dapat menentukan kombinasi terbaik yang efektif dan dapat diterapkan di lahan sawah untuk peningkatan produksi.

\section{METODE PENELITIAN}

\section{Tempat dan Waktu Penelitian}

Penelitian ini dilaksanakan di Desa Sulu Kecamatan Tatapaan Kabupaten Minahasa Selatan di lahan sawah petani sebagai kelompok tani penerima bantuan kegiatan SRI dari Dinas Pertanian dan Peternakan Provinsi Sulawesi Utara, pada bulan Mei sampai dengan Agustus 2014.

\section{Metode Penelitian}

Penelitian akan dilaksanakan dalam metode percobaan lapangan menggunakan rancangan petak terbagi dalam kelompok dari dua faktor. Sebagai faktor pertama adalah tipe tanam jajar legowo 2:1 dan 4:1. Sedangkan faktor kedua adalah pemberian paclobutrazol melalui penyemprotan pada tanaman dengan dosis: 1) 0 ppm, 2) 600 ppm. Paclobutrazol akan diberikan hanya sekali, yaitu pada saat tanaman dalam periode pertumbuhan vegetatif aktif (tanaman berumur sekitar 30 hari setelah pindah tanam).

Susunan perlakuan keseluruhan ada 4 kombinasi dengan 4 ulangan sehingga terdapat 16 satuan percobaan, ukuran petak $3,25 \mathrm{~m} \mathrm{x} 4$ $\mathrm{m}$ menggunakan cara tanam jajar legowo model 2:1 dan 4:1 dengan jarak tanam $25 \mathrm{~cm} \times 25 \mathrm{~cm}$, jarak 50 antar barisan kosong $50 \mathrm{~cm}$ dan terdapat jarak antara anak petak $75 \mathrm{~cm}$. 


\section{Alat dan Bahan}

Alat yang digunakan adalah rol meter, bajak, garu, landak, caplak, gelas ukur, sprayer, bambu, patok kayu, oven, timbangan, tali raffia, dan lain-lain.

Bahan tanaman yang digunakan adalah benih padi sawah varitas serayu (umur benih yang ditanam adalah 10 hari sesudah semai HSS), pupuk organic cair (POC), kompos, Zat pengatur tumbuh (ZPT) yang diuji berbahan aktif Paclobutrazol, pupuk Urea, pupuk SP 36, pupuk $\mathrm{KCl}$, telur dan larutan garam, dan lain-lain.

1. Tinggi Tanaman

2. Laju Tumbuh

3. Kandungan Klorofil Daun

4. Anakan Produktif

5. Panjang Malai

6. Berat 1.000 Butir

7. Berat Gabah Kering Giling per Petak

8. Jumlah Butir per Malai

\begin{abstract}
Analisis Data
Analisis data dilakukan dengan menggunakan perhitungan Interaksi Dua Faktor. Dua faktor dikatakan berinteraksi apabila pengaruh suatu faktor berubah pada saat perubahan taraf faktor lainnya berubah (Gomez dan Gomez, 1995)
\end{abstract}

\section{HASIL DAN PEMBAHASAN}

\section{Pertumbuhan Tanaman}

Dicks (1979) mendefinisikan zat penghambat tumbuh (retardan) sebagai senyawa-senyawa organik sintetik yang bisa diberikan kepada tanaman yang responsif menghambat perpanjangan sel pada meristem sub apikal, mengurangi laju perpanjangan batang tanpa mengurangi pertumbuhan dan perkembangan daun atau tanpa mendorong pertumbuhan yang abnormal. Wieland dan Wampe (1985) menyatakan, pemberian paclobutrazol efektif diberikan melalui daun dan tanah. Zat tersebut di translokasikan melalui jaringan xilem dan mencapai tunas pucuk. Sistem vasculer disebelah titik tumbuh berfungsi sebagai penyimpan zat pengatur tumbuh dan menghambat biosintesa asam giberelat sehingga mengakibatkan pertumbuhan dan pemanjangan tunas berhenti.
Lienargo, dkk (2013) menyatakan bahwa paclobutrazol mempengaruhi tinggi tanaman jagung Manado Kuning. Makin tinggi konsentrasi paclobutrazol yang diberikan, makin pendek tanaman jagung yang didapati. Menurut Sambeka (2012), pada tanaman kentang varitas Supejohn, kombinasi paclobutrazol $125 \mathrm{ppm}$ yang disemprot pada unur tanaman 6 MST mampu menekan pertumbuhan tinggi tanaman, meningkatkan kandungan klorofil total dan penyerapan radiasi matahari oleh tajuk tanaman (fraksi radiasi menjadi lebih kecil) serta meningkatkan bobot umbi pertanaman (dari $0.78 \mathrm{~kg}$ menjadi 1,88 $\mathrm{kg}$ ) dan meningkatkan bobot umbi per petak (dari 16,40 kg menjadi 45,04 kg)

Secara umum hasil penelitian ini menunjukkan adanya interaksi antara perlakuan paclobutrazol dan tanam jajar paclobutrazol dan tanam jajar yaitu interaksi tinggi pada penghambatan pertumbuhan vegetatif tanaman padi sawah varitas Serayu, interaksi pertengahan terhadap laju tumbuh tanaman serta berinteraksi tinggi terhadap peningkatan jumlah klorofil b pada daun. Pada gambar 1 menunjukkan interaksi yang tinggi antara perlakuan PBZ dan JL terhadap penghambatan tinggi tanaman. Hasil penelitian menunjukkan terdapat respon PBZ positif untuk kedua sistem tanam JL tetapi respon JL 2:1 lebih tinggi $(-13,85 \mathrm{~cm})$ daripada JL 4:1 (-8,23 cm) menjadikan pengaruh interaksi antara faktor PBZ dan JL sebesar 2,77 $\mathrm{cm} /$ tanaman.

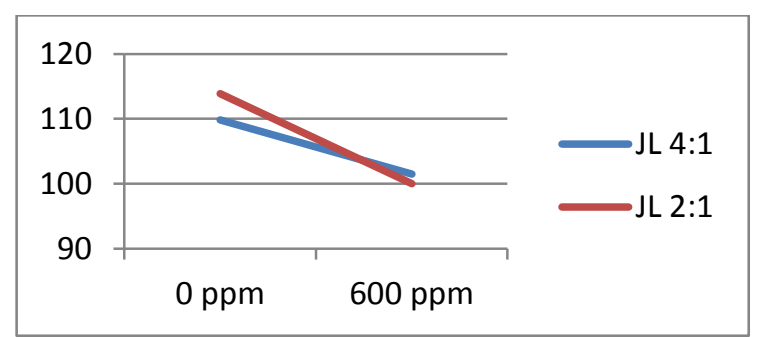

Gambar 1. Tinggi Tanaman Padi Sawah Varitas Serayu 13 MST

Pada laju tumbuh tanaman menunjukkan interaksi pertengahan perlakuan PBZ pada JL. Pengaruh sederhana PBZ pada JL 2:1 (-9,12 gr) dan untuk JL 4:1 (13,8 gr), pengaruh utamanya menjadi 2,34 gr. Dengan kata lain meskipun terdapat respon yang besar terhadap pemberian PBZ untuk JL 4:1 tetapi negatif untuk JL 2:1 menjadikan pengaruh interaksi 2,34 gr per tanaman. Interaksi pertengahan laju tumbuh dapat dilihat pada gambar 2 . 


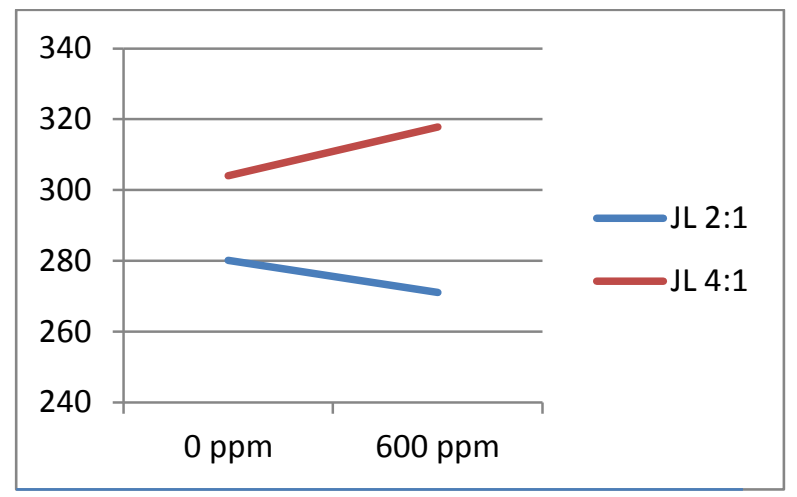

Gambar 2. Laju Tumbuh pada 12 MST

Zeng, dkk (2011) menyatakan hasil penelitian perlakuan Paclobutrazol (PBZ) dan Chlorocholine chlorida (CCC) masing-masing secara terpisah (keduanya menggunakan 300 $\mathrm{mg} / \mathrm{l}$ ) pada tanaman Lilium Oriental hibrida 'Sorbonne', sangat efisien meningkatkan kandungan klorofil b pada usia tanaman 14 MST. Kandungan klorofil b pada perlakuan PBZ dan CCC meningkat lebih tinggi menjadi $536,98 \%$ dan $793,82 \%$ dari pada kontrol. Kandungan klorofil total kemudian menjadi lebih tinggi dengan perlakuan PBZ dan CCC dari pada tanaman kontrol saat setelah berbunga. Sambeka (2012) menyatakan, kandungan klorofil total pada daun kentang varitas Supejohn meningkat seiring besarnya konsentrasi paclobutrazol. Hasil penelitian menunjukkan interaksi pertengahan pada perlakuan PBZ dan JL untuk peningkatan kandungan klorofil a dan klorofil $b$ pada daun. Interaksi pertengahan untuk klorofil a dan klorofil b ditunjukkan pada gambar 3 dan Gambar 4.

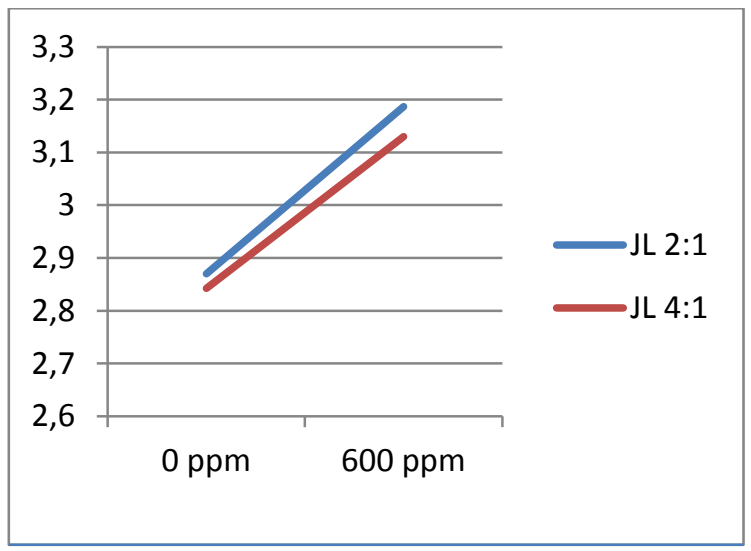

Gambar 3. Kandungan Klorofil a Untuk Interaksi Dua Arah

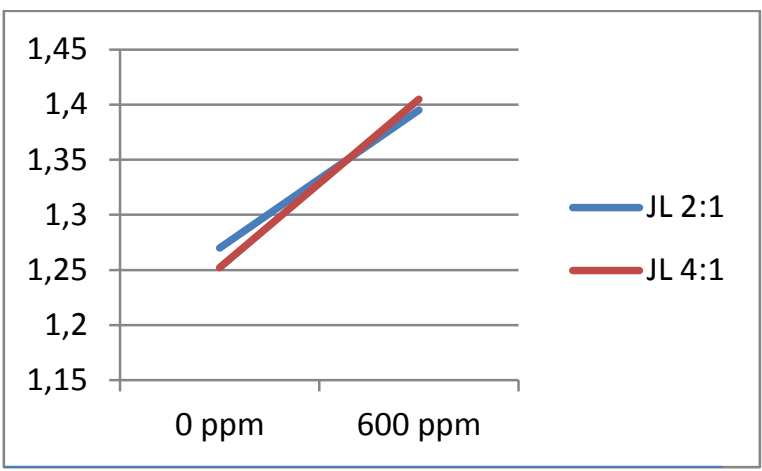

Gambar 4. Kandungan Klorofil b Untuk Interaksi Dua Arah

Sesuai hasil analisis interaksi dua faktor kandungan klorofil a menunjukkan pengaruh sederhana PBZ pada JL 2:1 (0,32 gr) dan pada JL 4:1 (0,29 gr), pengaruh utamanya adalah 0,31 gr. Hasil penelitian menunjukkan terdapat respon positif terhadap pemberian PBZ pada JL 2:1 dan negatif pada JL 4:1. Menjadikan pengaruh interaksi 0,02 gr per helai daun.

Pada hasil penelitian klorofil $b$ menunjukkan pengaruh sederhana PBZ pada JL 4:1 (0,16 gr) dan pada JL 2:1 ( $0,13 \mathrm{gr})$, pengaruh utamanya adalah 0,15 gr. Hasil menunjukkan respon besar PBZ pada JL 2:1 dan kurang pada JL 4:1. Menjadikan pengaruh interaksi 0,02 gr per helai daun.

\section{Komponen Hasil}

Komponen hasil yang diamati adalah anakan produktif, panjang malai, berat 1.000 butir, berat gabah giling per petak dan jumlah butir per malai. Hasil penelitian Misran (2014) pada pengamatan padi VUB Batang Piaman menyatakan bahwa pada hasil penelitiannya panjang malai berkisar $21,8-30,8 \mathrm{~cm}$, dimana malai terpanjang didapat pada jajar legowo 2:1 $(30,8 \mathrm{~cm})$ dan berbeda nyata dengan perlakuan lainnya. Jumlah gabah per malai berkisar 120,0 143,3 butir, dimana yang terbanyak didapat pada perlakuan jajar legowo 4:1 (143,3 butir) dan berbeda nyata dengan perlakuan lainnya. Ada kecenderungan bahwa semakin banyak populasi tanaman maka jumlah gabah juga semakin meningkat. Selanjutnya Misran menyatakan terdapat presentasi peningkatan hasil gabah kering panen berkisar 19,90-22,00\% dibandingkan tanpa jajar legowo. Rata-rata hasil gabah yang diperoleh pada perlakuan jajar legowo 2:1 6,40 ton per ha), jajar legowo 4:1 (6,45 ton per ha), jajar legowo 6:1 (6,24 ton per ha) dan jajar legowo 8:1 (6,30 ton per ha) dan bebeda nyata dengan perlakuan tanpa jajar legowo (4,25 ton per ha). 
Harun, dkk (2012) menyatakan perlakuan jarak tanam jajar legowo 4:1 memiliki jumlah anakan produktif (14.43) yang berbeda nyata dengan jarak tanam lainnya yaitu jajar legowo 2:1 dan 3:1 pada padi varitas Impari 13. Sirappa (2011) menyatakan sistem tabela legowo 4:1 rata-rata memberikan anakan produktif per rumpun lebih tinggi dari sistem tabela legowo 2:1 yaitu masing-masing 29 anakan (27-32 anakan), jauh lebih tinggi dari dibandingkan dengan anakan produktif berdasarkan deskripsi varitas 14-17 anakan).

Menurut Field (1989), paclobutrazol meningkatkan jumlah cabang tanaman kacang polong pada setiap tanaman dari 0.8 menjadi 0.9 (SE 0,09) sementara itu berat kering tanaman meningkat 4,9 menjadi 6,7 g (SE $0,46)$. Paclobutrazol juga menginduksi produksi buah polong dengan memaksimalkan potensi batang utamanya, keuntungan sebenarnya adalah berhubungan dengan kemampuan tanaman membuat percabangan.

Pengaruh interaksi perlakuan paclobutrazol dan jajar legowo terhadap jumlah anakan produktif sesuai gambar 5 menunjukkan adanya interaksi yang tinggi. Respon pemberian PBZ yang positif besar untuk JL 4:1 (10,45 anakan per rumpun) tetapi respon negatif pada JL 2:1 (2,6 anakan per rumpun), pengaruh utama PBZ 6,53 anakan per rumpun menjadikan interaksi 3,93 anakan per rumpun.

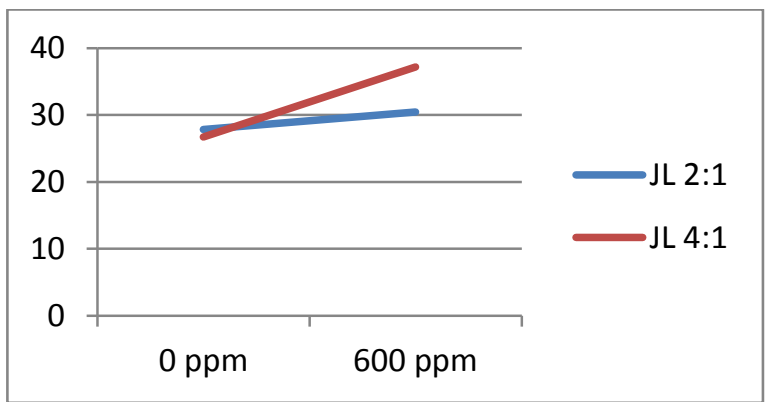

Gambar 5. Anakan Produktif

Pengaruh interaksi perlakuan paclobutrazol dan jajar legowo terhadap panjang malai sesuai gambar 6 menunjukkan adanya interaksi yang tinggi. Respon pemberian PBZ yang positif untuk JL $4: 1(0,37 \mathrm{~cm})$ tetapi respon negatif pada JL 2:1 $(-0,72 \mathrm{~cm})$, pengaruh utama PBZ -0,18 anakan per rumpun menjadikan interaksi 3,93 anakan per rumpun. Panjang malai pada JL 2:1 menghasilkan lebih dari $0,37 \mathrm{~cm}$ pada PBZ 0 ppm tetapi menghasilkan kurang dari 0,37 pada PBZ 600 ppm.

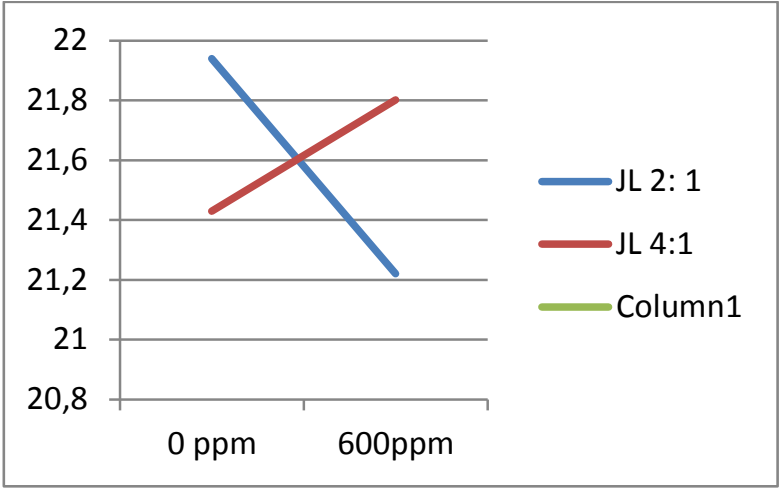

Gambar 6. Panjang Malai

Pengaruh interaksi perlakuan paclobutrazol dan jajar legowo terhadap peningkatan berat 1.000 butir sesuai gambar 7 menunjukkan adanya interaksi pertengahan. Respon pemberian PBZ yang positif besar untuk JL 2:1 (1,61 gr) tetapi respon negatif pada JL 4:1 (0,81 gr), pengaruh utama PBZ 0,99 gr menjadikan interaksi pertengahan 0,18 gr.

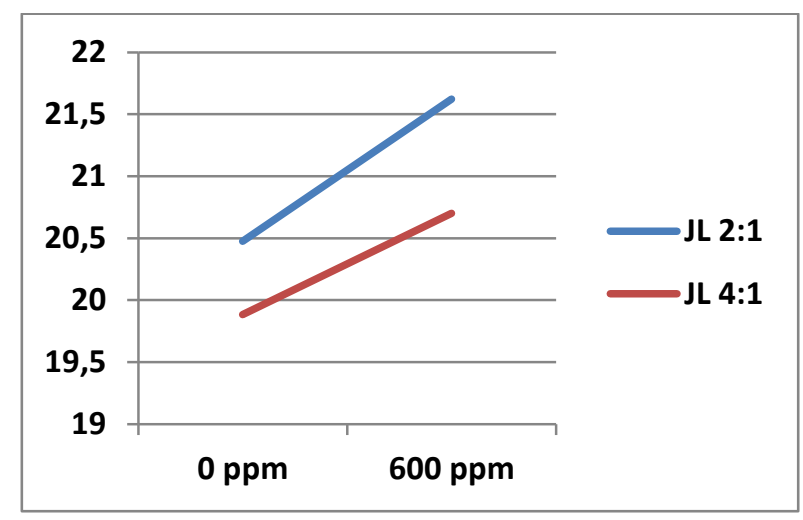

Gambar 7. Berat 1.000 Butir

Menurut Sirappa (2011), sistem tabela legowo 2:1 rata-rata memberikan hasil gabah yang lebih tinggi $\left(5,96\right.$ t GKG ha $\left.^{-1}\right)$ dibandingkan tabela legowo 4:1 yaitu $5,47 \mathrm{t}$ GKG ha ${ }^{-1}$ pada padi sawah varitas IR66. Hal ini diduga adanya kaitan dengan gabah hampa dimana sistem legowo 2:1 (21 jumlah gabah hampa per malai) mempunyai presentase gabah hampa lebih rendah dibandingkan dengan legowo 4:1 (30 gabah hampa per malai). Legowo 2:1 memiliki rata-rata jumlah gabah isi per malai 107 dan legowo 4:1 memiliki gabah isi per malai yang lebih rendah yaitu 93. Sistem tabela legowo 2:1 mempunyai presentase gabah hampa yang lebih rendah, diduga karena pengaruh dari effek tanaman pinggiran (border effect) dimana tanaman pinggiran diharapkan semuanya produktif. 
Pengaruh interaksi perlakuan paclobutrazol dan jajar legowo terhadap peningkatan berat Gabah Kering Giling per petak sesuai gambar 8 menunjukkan adanya interaksi yang tinggi. Respon pemberian PBZ yang positif pada JL $2: 1(0,87 \mathrm{gr})$ tetapi respon negatif pada JL 4:1 (-0,08 gr), pengaruh utama PBZ 0,40 gr menjadikan interaksi pertengahan 0,48 gr per petak.

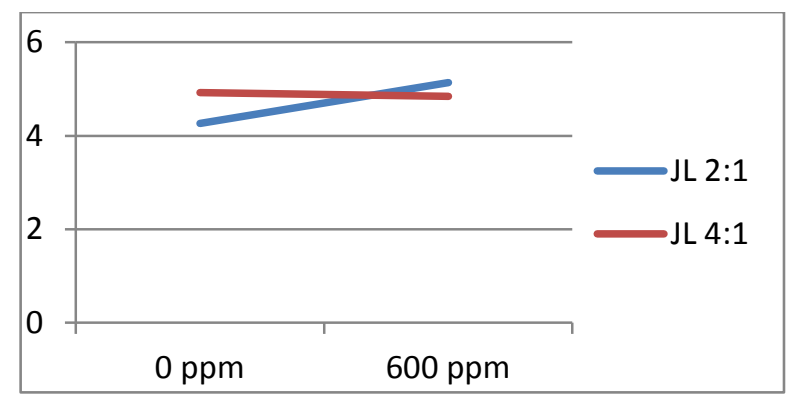

Gambar 8. Berat Gabah Kering Giling per petak

Pengaruh interaksi perlakuan paclobutrazol dan jajar legowo terhadap peningkatan jumlah butir per malai sesuai gambar 8 menunjukkan tidak adanya interaksi. Perlakuan PBZ 600 ppm mendapat respon negatif pada JL 4:1 dan JL 2:1.

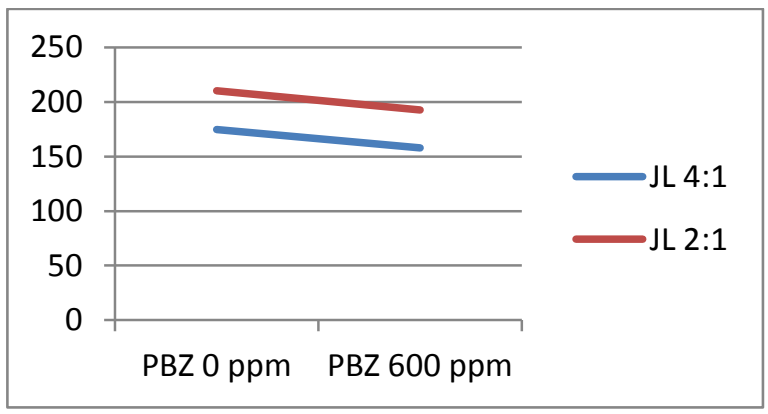

Gambar 9. Jumlah Butir per Malai

\section{KESIMPULAN DAN SARAN}

\section{Kesimpulan}

1. Perlakuan paclobutrazol 600 ppm memberikan respon positif pada JL 2:1 untuk penghambatan pertumbuhan vegetative tanaman untuk mencegah tanaman terlalu tinggi dan tidak mudah rebah, peningkatan kandungan klorofil a, meningkatkan berat 1.000 butir dan meningkatkan berat gabah kering giling per petak.
2. Perlakuan paclobutrazol 600 ppm memberikan respon positif pada jajar legowo 4:1 untuk peningkatan laju tumbuh, peningkatan kandungan klorofil $b$, peningkatan jumlah anakan produktif dan panjang malai.

\section{Saran}

1. Penggunaan paclobutrazol $600 \mathrm{ppm}$ dengan sistem tanam jajar legowo 2:1 atau 4:1 dapat di aplikasikan di lahan sawah karena berinteraksi positif pada peningkatan produksi

2. Untuk meminimalkan kerusakan hasil karena tanaman terlalu tinggi yang bisa menyebabkan tanaman rebah dapat menggunakan retardan paclobutrazol atau memilih varitas tanaman padi yang secara genetika tidak tinggi seperti varitas IR66 yang memiliki tinggi berkisar 87,33 - 91,50 cm (Sirappa, 2007)

3. Guna peningkatan hasil produksi tanaman padi sawah dapat menggunakan sistem tanam jajar legowo seperti jajar legowo 2:1 untuk kemudahan pemeliharaan tanaman dari gulma dan penaggulangan hama penyakit serta dengan memperhatikan teknologi pertanian lainnya seperti penggunaan pupuk dan pestisida yang sesuai bahkan arahan pemerintah melakukan tanaman padi serentak pada suatu hamparan guna meminimalkan kehilangan hasil akibat serangan hama.

\section{DAFTAR PUSTAKA}

Berova, M. and Zlatev, Z. 2000.Physiological Response and Yield of Paclobutrazol Treated Tomato Plants (Lycopersicon esculentum Mill).Plant Growth Regulator. 30(2): 117-123. Kluwer Academic Publhiser.

Chaney, E. R. 2004. Paclobutrazol: More Than Just a Growth Retardant. Pro-Hort Conference, Peoria, Illinois, February 4th. Department of Forestry and Natural Resources.Purdue University.

Direktorat Jenderal Pengelolaan Sarana dan Prasarana Pertanian Kementerian Pertanian RI. 2014. Pedoman Teknis Budidaya SRI. Jakarta. 
Field R, J., G.D. Hill, H. J. Attiya, H. Effendi. 1989. Plant Growth Regulators And Grain Legumes. Plant Science Department Lincoln College Canterbury, New Zealand.

Guler Semiha. 2009. Effects of Nitrogen On Yield and Chlorophyll of Potato (Solanum tuberosum L.) Cultivars.Black Sea Agricultural Research Insstitute, 55001 Samsun, Turkey.

Hanum, C. 2008. Teknik Budidaya Tanaman. Direktorat Pembinaan Sekolah Menengah Kejuruan. ISBN 978-979-060-057-7.

Harjadi, S. S. 1996. Pengantar Agronomi. PT. Gramedia Pustaka Utama. Jakarta. 197hal.

Harun Rizan, Nelson Pomalingo, Fauzan Zakaria. 2012. Sistem Tanam Jajar Legowo Dengan Kombinasi Dosis Pupuk Phonska dan Urea Terhadap Pertumbuhan dan Hasil Tanaman Padi Sawah (Oryza sativa L.) varitas Inpari 13.Seminar Hasil Penelitian. Universitas Negeri Gorontalo.

Hermanto, D. Sadikin W., E. Hikmat. 2009. Deskripsi Varietas Unggul Padi 1943 2009. Puslitbang Tanaman Pangan. Balitbang Pertanian. 220 hal.

Lienargo Bonaventura Rizky, Semuel D. Runtunuwu, Johannes E.X. Rogi, Pemmy Tumewu.

Lingga, P. dan Marsono. 2004. Petunjuk Penggunaan Pupuk. Penebar Swadaya. Jakarta. 150hal.

Misran.2014. Studi Sistem Tanam jajar Legowo Terhadap Peningkatan Produktivitas Padi Sawah. Jurnal Penelitian Pertanian Terapan Vol. 14 (2): 106-110. ISSN 1410-5020.

Muyassir. 2012. Efek Jarak Tanam, Umur dan Jumlah Bibit Terhadap Hasil Padi Sawah (Oryza sativa L.). Jurnal Manajemen Sumber Daya Lahan, Volume 1, Nomor 2, Desember 2012: hal.2017-212
Pan Shenggang, Fahd Rasul, Wu Li, Hua Tian, Zhaowen Mo, Meiyang Duan, Xiangru Tan. 2013. Roles of Plant Growth Regulators On Yield, Grain Qualities and Antioxidant Enzyme Activities in Super Hybrid Rice (Oryza sativa L.)

Purwasamita, M dan A. Sutaryat.2014. Padi SRI Organik Indonesia. Penebar Swadaya Jakarta

Zheng Ri-ru, Yun Wu, Yi Ping Xia. (2011). Chlorocholine Chloride and Paclobutrazol Treatments Promote Carbohyrate Accumulation In Bulbs of Lilium Oriental Hybrids 'Sorbone'. Journal of Zhejiang University- Science B (Biomedicine and Biotechnology), ISSN 1573-1581 (Print): ISSN 1862-1783.

Runtunuwu, S. D. dkk,. 2010. Aplikasi Paclobutrazol untuk Pengembangan Kualitas dan Produktivitas Cengkeh di Kabupaten Minahasa Selatan. Laporan Hasil Penelitian. PT Hanjaya Mandala Sampoerna Tbk.

Runtunuwu, S. D., P. Tumewu, D.M.F. Sumampouw, S. Walingkas, dan ARMN.Rengkung. 2013. Penggunaan Retardan Untuk Meningkatkan Produksi Padi Sawah. Laporan Penelitian. Fakultas Pertanian Unsrat dan Dinas Pertanian Prov. Sulut.

Sambeka, F., S. D. Runtunuwu, dan J. E. X. Rogi. 2012. Efektifitas Waktu Pemberian dan Konsentrasi Paclobutrazol Terhadap Pertumbuhan dan Hasil Kentang Varitas Supejohn. Eugenia 18(2): 126-133.

Sarief, E. S. 1983. Kesuburan dan Pemupukan Tanah Pertanian. Pustaka Buana. Bandung. 182hal.

Setyamidjaya, D. 1986. Pupuk dan Pemupukan. CV Simplex. Jakarta. 120hal. Thompson, H. C. and W. C. Nelson. 1977. Vegetable Crops. 2nd Mc.Grow-Hill Book Co. Inc. London. 422p. 
Sirappa Marthen P. 2011. Kajian Perbaikan Teknologi Budidaya Padi Melalui Penggunaan Varietas Unggul dan Sistem Tanam Jajar Legowo Dalam Meningkatkan Produktivitas Padi Mendukung Swasembada Pangan. Jurnal Budidaya Pertanian 7: 70-86.

Sudarsono dan A. Karim Makarim.2008. Peningkatan Hasil Padi Melalui Perbaikan Cara Tanam Jajar Legowo dan Indtroduksi Varietas Unggul di Distrik Kurik Kabupaten Merauke Papua.Jurnal. Balai Pengkajian Teknologi Pertanian Papua Merauke, Balai Besar Penelitian Tanaman Padi.
Sumardi.dkk,. 2007. Respon Padi Sawah pada Teknik Budidaya Secara Aerobik dan Pemberian Bahan Organik.Jurnal Akta Agrosia Vol.10 No.1 hlm 65-71.ISSN 1410-3354.

Wahyu A. 2010. Tanam Padi Cara Jajar Legowo di Lahan Sawah. http://banten litbang.deptan.go.id/ind/index.php. Diakses pada tanggal 29 Mei 2014.

Wattimena, G. A. 1988. Zat Pengatur Tumbuh Tanaman. Lab. Jaringan Tanaman. PAU $\mathrm{B}=$ Lioteknologi IPB. Bogor. 145hal. 